\title{
New wheat genotypes tolerant to aluminum toxicity obtained by mutation induction ${ }^{(1)}$
}

\author{
Augusto Tulmann Neto(2), Marcelo Correa Alves ${ }^{(3)}$, Carlos Eduardo de Oliveira Camargo ${ }^{(4)}$, \\ Jairo Lopes de Castro( ${ }^{(4)}$ e Wilson Penteado Ferreira Filho(4)
}

\begin{abstract}
Seed from the sensitive wheat (Triticum aestivum L.) cultivar Anahuac was treated to gammaray irradiation and eleven $\mathrm{Al}^{3+}$ tolerant mutants selected. The objective was to compare these mutants to the original Anahuac and to the tolerant wheat cultivars IAC-24 and IAC-60 from 1994 to 1996 in acid (Capão Bonito) and limed (Monte Alegre do Sul) soil field trials, in the State of São Paulo, Brazil. Grain yield and agronomic characteristics were analyzed. All the mutant lines yielded higher than the sensitive Anahuac cultivar in the acid soils of Capão Bonito. Under limed soil conditions, 10 mutants had a similar yield to the original sensitive cultivar and one a lower yield. The majority of the mutants were similar in yield to the tolerant cultivars IAC-24 and IAC-60 under both conditions. Some of the mutants showed altered agronomic characteristics, but these alterations did not generally influence the grain yield. The results indicated that tolerant lines with good characteristics may be obtained from a susceptible cultivar by mutation induction, thus allowing cropping under conditions where $\mathrm{Al}^{3+}$ is a limiting factor.
\end{abstract}

Index terms: acid soil, liming, breeding methods, mutants, gamma radiation, agronomic characters, grain yield, plant breeding.

\section{Novos genótipos de trigo tolerantes a toxicidade de alumínio obtidos por meio de indução de mutação}

Resumo - Onze mutantes tolerantes a $\mathrm{Al}^{3+}$ foram selecionados a partir de sementes da cultivar de trigo (Triticum aestivum L.) sensível Anahuac, tratadas com raios-gama. O objetivo deste trabalho foi comparar esses mutantes com a cultivar original e as tolerantes IAC-24 e IAC-60 de 1994 a 1996, em ensaios de campo em solo ácido (Capão Bonito) e corrigido (Monte Alegre do Sul) no Estado de São Paulo. Produção de grãos e várias características agronômicas foram analisadas. Todas as linhagens mutantes produziram mais que a cultivar sensível em solos ácidos em Capão Bonito. Em solos corrigidos, dez mutantes apresentaram produção similar à Anahuac original e um, menor produção. A maioria dos mutantes apresentou produção similar à das cultivares tolerantes IAC-24 e IAC-60 em ambas as condições. Alguns dos mutantes mostraram alterações em características agronômicas, mas tais alterações em geral não afetaram a produção de grãos. Os resultados indicaram que linhagens tolerantes com boas características podem ser obtidas de cultivares sensíveis a partir de indução de mutação, permitindo o cultivo em condições nas quais o $\mathrm{Al}^{3+}$ é um fator limitante.

Termos para indexação: solo ácido, calagem, métodos de melhoramento, mutante, raios-gama, características agronômicas, rendimento de grãos, melhoramento de plantas.

\footnotetext{
(1) Accepted for publication on January 26, 2000.

${ }^{(2)}$ Universidade de São Paulo (USP), Centro de Energia Nuclear na Agricultura (CENA), Caixa Postal 96, CEP 13400-970 Piracicaba, SP. E-mail: tulmannneto@cena.usp.br

${ }^{(3)}$ Centro de Informática na Agricultura (CIAGRI), USP, Caixa Postal 9, CEP 13418-900 Piracicaba, SP.

E-mail: macalves@carpa.ciagri.usp

(4)Instituto Agronômico (IAC), Caixa Postal 28, CEP 13020-902 Campinas, SP. E-mail: cccamargo@cec.iac.br, ferreira@cec.iac.br
}

\section{Introduction}

Breeding for aluminum tolerant cultivars is among the main objectives of wheat (Triticum aestivum L.) breeding in the State of São Paulo (Camargo, 1993) since $\mathrm{Al}^{3+}$ sensitivity is an important limiting factor for yield in the majority of acid soils. Deficiency in an agronomic characteristic, such as aluminum tolerance may be corrected in a cultivar which has a series of other good traits by using chemical or physical mutagens. 
Wheat mutation induction has been used in Brazil with several objectives, and mutants for earliness, plant height, disease resistance and $\mathrm{Al}^{3+}$ toxicity tolerance have been obtained (Camargo et al., 1996; Tulmann Neto et al., 1996). In the case of the sensitive cultivar Anahuac, the objective was to obtain $\mathrm{Al}^{3+}$ tolerance mutants without alteration to the basic characteristics of the cultivar following the previously described strategy. As in other crops, once the mutant is obtained, it is necessary to test its performance in various locations and years prior to deciding whether it may substitute the original cultivar or will need to be intercrossed in a breeding program.

Mutants obtained from gamma-rays irradiated seeds of the sensitive wheat cultivar Anahuac previously screened in nutrient solution for $\mathrm{Al}^{3+}$ tolerance (Camargo et al., 1987) were further selected under field conditions. The present study was carried out to assess the mutant lines and the original Anahuac, IAC-24 and IAC-60 cultivars.

\section{Material and Methods}

Eleven 'Anahuac' mutant lines (numbered mutant 18 to 28), tolerant to $\mathrm{Al}^{3+}$ toxicity in nutritive solutions (using method proposed by Camargo \& Oliveira, 1981), were assessed under field conditions, in two location of the State of São Paulo, Brazil. These mutant lines were obtained after field selection in the $\mathrm{M}_{3}$ generation derived from seeds of Anahuac treated with $260 \mathrm{~Gy}$ (mutant lines 18 to 24) and $310 \mathrm{~Gy}$ (mutant lines 25 to 28 ) gamma-rays as described by Camargo et al. (1996).

The cultivars Anahuac, of Mexican origin, semidwarf, early cycle and sensitive to $\mathrm{Al}^{3+}$ toxicity; IAC-24, semidwarf, early cycle and tolerant to $\mathrm{Al}^{3+}$ and IAC-60, average height, medium cycle and tolerant to $\mathrm{Al}^{3+}$ were used as controls in the experiments. The last two cultivars were selected from crosses of the Instituto Agronômico de Campinas (IAC) wheat breeding program.

Three experiments were set up at the Capão Bonito Experimental Station, São Paulo State, under upland and acid soil (Latosol) conditions (climate wheat zone B), in March, 1994, 1995 and 1996. Two experiments were also sown at the Monte Alegre do Sul Experimental Station, São Paulo State (climate zone H), in limed soil (Podzol) under sprinkler irrigation, in April, 1994 and 1995. The climate wheat zones were established according to the rain distribution and temperature (Instituto Agronômico, 1996). A randomized complete block experimental design, with four replications per location was used. Each trial was made up of 80 plots, each one formed by six 3-meter rows, spaced at $0.20 \mathrm{~m}$. A $0.60 \mathrm{~m}$ space was left between plots. Eighty viable seeds/meter were sown, totaling 1,440 seeds per plot, in an evaluated area of $3.6 \mathrm{~m}^{2}$. The fertilizers were spread on the soil before the seeding time and after that they were incorporated into the soil. The amount of the applied fertilizers in the two locations were based on the fertilizers recommendations tables of Instituto Agronômico (Ray et al., 1985). In Table 1 the results of the soil analysis carried out in Capão Bonito and Monte Alegre do Sul are presented.

The following data were collected: period from emergence to flowering and maturity (flowering and life cycle), lodging (scale 0 without lodging to 5 maximum lodging), plant height, spike length, number of spikelets per spike, grains per spike and spikelet, weight of 100 grains and grain yield. These parameters were assessed according to Camargo et al. (1991).

Other characteristics such as spike length, number of spikelets per spike, number of grains per spike and per spikelet and weight of 100 grains which are related to yield components were analyzed in the Monte Alegre do Sul experiment, only in 1994, to have a preliminary comparison between the mutants and original Anahuac for these characteristics.

A joint analysis of variance for years at each location, for the assessed parameters, except yield components, was carried out. An analysis of the residual mean squares was performed to check for discrepancies and validate the joint analysis.

The assumptions of the analysis of variance were checked before proceeding to the joint analysis in order to detect and correct problems of scale of the variable response, the presence of outliners, absence of variance equality, excessively influential values and design problems. This analysis was carried out using the LBA software from SAS and whenever necessary the indicated transformation was adopted to obtain the maximum likelihood.

The joint analysis of variance was carried out and significance at the $5 \%$ level was considered. In cases where a significant effect of interaction was detected, the Tukey test was carried out independently for each year, but based on the pooled residual obtained in the joint analysis of variance. The STAT software in SAS was used for this analysis. Individual analysis of variance and means comparison by the Tukey test were carried out for the yield components analyzed in the experiment at Monte Alegre do Sul, in 1994. 


\section{Results and Discussion}

Working with wheat mutants, Barriga et al. (1996) indicated the need to establish yield stability by analyzing production for several years and locations before a final recommendation is made. As pointed out by Maluszynski et al. (1995), mutants obtained after mutagenic treatment are very often released directly to farmers after yield trials, but could also be included as improved germplasm in breeding programs. They observed that in wheat cropping for bakeries, only 35 out of 140 mutant cultivars were obtained from indirect use in crosses. This means that in the majority of cases there were no large alterations induced by the mutagenics in the original material. However, in several selected wheat mutants obtained in other countries, alterations have been found for other characteristics besides the object of the original selection (Donini et al., 1984).

\section{Grain yield}

The genotype (mutant lines and cultivars), year and genotype and year interaction mean squares in the joint analysis of variance for grain yield for the experiments at Capão Bonito (1994-96) were significant. In these experiments, under upland conditions in acid soil, and base saturation percentages of 22 on the arable layer, the yield results (Table 2) showed that the control cultivars IAC-60

Table 1. Soil analysis of the trials locations at the depth of $0-20 \mathrm{~cm}^{(1)}$.

\begin{tabular}{lcc}
\hline Determinations & $\begin{array}{c}\text { Capão } \\
\text { Bonito }\end{array}$ & $\begin{array}{c}\text { Monte Alegre } \\
\text { do Sul }\end{array}$ \\
\hline P resin $(\mathrm{mg} / \mathrm{kg})$ & 16.0 & 78.0 \\
$\mathrm{M} . \mathrm{O} .(\mathrm{g} / \mathrm{kg})$ & 30.0 & 25.0 \\
$\mathrm{pH}\left(\mathrm{CaCl}_{2}\right)$ & 4.6 & 4.9 \\
$\mathrm{~K}\left(\mathrm{mmol}_{\mathrm{c}} / \mathrm{dm}^{3}\right)$ & 1.2 & 4.1 \\
$\mathrm{Ca}\left(\mathrm{mmol}_{\mathrm{c}} / \mathrm{dm}^{3}\right)$ & 24.0 & 35.0 \\
$\mathrm{Mg}\left(\mathrm{mmol}_{\mathrm{c}} / \mathrm{dm}^{3}\right)$ & 5.0 & 12.0 \\
$\mathrm{H}+\mathrm{Al}\left(\mathrm{mmol}_{\mathrm{c}} / \mathrm{dm}^{3}\right)$ & 72.0 & 52.0 \\
$\mathrm{~S}\left(\mathrm{mmol}_{\mathrm{c}} / \mathrm{dm}^{3}\right)$ & 20.0 & 51.0 \\
$\mathrm{~T}\left(\mathrm{mmol}_{\mathrm{c}} / \mathrm{dm}^{3}\right)$ & 92.0 & 103.0 \\
V $(\%)$ & 22.0 & 50.0 \\
\hline (1) Analysis made at the Centro de Solos e Recursos Agroindustriais, Insti- \\
tuto Agronômico de Campinas, SP, Brazil.
\end{tabular}

and IAC-24 were tolerant, and Anahuac, a cultivar very sensitive to aluminum toxicity. Table 2 shows comparison of the mutants and the original Anahuac cultivar using the Tukey test. The mutant yields were higher in all years indicating the advantages of the aluminum tolerance obtained for this soil condition. The comparison among the 11 mutants showed, as indicated by the significant interaction among genotypes and years in the analysis of variance, that some mutants have higher yield (or lower) than others depending on the year. In 1995 the mutant 23 had a higher yield than mutants 18 and 27, but in 1994 and 1996 their yields were similar. It must be emphasized that, in the three years, several mutants (mutants 20, 23, 26, 27 and 28, for example) had high yield means similar to those of the tolerant controls IAC-60 and IAC-24.

The joint analysis of variance mean squares for yield in the experiments in Monte Alegre do Sul (1994-1995) indicated that the year and genotypes effects were significant. On the other hand, the genotype $\mathrm{x}$ year interaction effects were not significant (Table 3). When the Tukey test was applied for the comparison of the genotypes' grain yield means for the two years, it was found that only mutant 25 yielded less than the original Anahuac cultivar and the other two IAC cultivars. The other mutants had similar yields to those of the tolerant controls. This indicates that ten of the mutants selected for tolerance to $\mathrm{Al}^{3+}$ toxicity were as productive in limed soils as in acid soils. Similar to the results obtained in Capão Bonito, mutants 20, 26, 27 and 28 had high yield levels.

In the present work, tolerant mutants were found. The experiments under acid soil conditions showed that all the mutants yield more than the original cultivar; but under limed soil there was no difference among the genotypes, except for mutant 25 , which produced less. The grain yield results obtained for the two studied locations are in agreement with those obtained by Felicio et al. (1998). They demonstrated that the grain yield of different genotypes was reduced $50 \%$ under acid soil and upland condition, in comparison with limed soil and irrigated soil.

\section{Lodging}

Table 4 indicates that in Capão Bonito there were significant lodging effects for years, genotypes and 
interaction. The comparison of the means within years shows that lodging was low for all the genotypes. In 1995 there were no differences among the genotypes and in 1994 and 1996, various mutants had greater lodging values than the original Anahuac cultivar. Lodging resistance is related to plants with a vigorous and healthy root system, short and sturdy straw, resistant straw that does not break in the wind and resistance to disease pathogens and insects that attack and weaken the straw and root system (Poehlmann $\&$ Sleper, 1995). In the present case the results indicated that mutant plants presented the highest lodging percentage. Under acid soil in Capão Bonito the tolerant to aluminum toxicity mutants showed normal development, but the original Anahuac cultivar presented low plant development due to its high sensibility to aluminum toxicity. This may be explained when the mean heights for the original Anahuac cultivar (Table 5) are observed; as it is sensitive to aluminum and generally had lower plant height as a reflex of the damaging $\mathrm{Al}^{3+}$ effect. Although the greater plant height is obviously not solely responsible for greater lodging (Poehlmann \& Sleper, 1995), it is doubtless one of the important factors in its occurrence.

The interaction was not significant among genotypes and years in Monte Alegre do Sul (Table 4). Comparison of the mutants and the original cultivar showed no significant differences. Mutant 25 had the lowest lodging values comparatively to those of the other mutants, except mutants 19, 22 and 24. Six of the mutants had greater lodging than IAC-24 and IAC-60.

\section{Plant height}

The comparison of the means in 1994 indicated that the majority of mutants had no plant height differences to the original Anahuac cultivar, but the

Table 2. Mean grain yield (kg/ha) of wheat genotypes in the experiments at Capão Bonito, 1994-1996(1).

\begin{tabular}{|c|c|c|c|c|}
\hline Genotypes & 1994 & 1995 & 1996 & $1994 / 1996$ \\
\hline Anahuac mutant 18 & $1,327 \mathrm{ab}$ & $1,028 \mathrm{c}$ & $837 \mathrm{ab}$ & 1,064 \\
\hline Anahuac mutant 19 & $1,424 a b$ & $1,215 \mathrm{bc}$ & $872 \mathrm{ab}$ & 1,170 \\
\hline Anahuac mutant 20 & $1,222 \mathrm{ab}$ & $1,799 \mathrm{ab}$ & 934ab & 1,318 \\
\hline Anahuac mutant 21 & $1,257 \mathrm{ab}$ & $1,778 \mathrm{ab}$ & $920 \mathrm{ab}$ & 1,318 \\
\hline Anahuac mutant 22 & $1,229 \mathrm{ab}$ & $1,271 \mathrm{bc}$ & $771 \mathrm{ab}$ & 1,090 \\
\hline Anahuac mutant 23 & $1,396 \mathrm{ab}$ & $1,826 a b$ & $1,004 \mathrm{a}$ & 1,409 \\
\hline Anahuac mutant 24 & $958 b$ & $1,417 \mathrm{abc}$ & $792 a b$ & 1,056 \\
\hline Anahuac mutant 25 & $1,188 \mathrm{ab}$ & $1,563 \mathrm{abc}$ & $483 b$ & 1,078 \\
\hline Anahuac mutant 26 & $1,500 \mathrm{ab}$ & $1,465 \mathrm{abc}$ & $1,247 \mathrm{a}$ & 1,404 \\
\hline Anahuac mutant 27 & $1,576 a b$ & $1,431 \mathrm{abc}$ & $1,271 \mathrm{a}$ & 1,426 \\
\hline Anahuac mutant 28 & $1,479 \mathrm{ab}$ & $1,576 a b c$ & $1,351 \mathrm{a}$ & 1,469 \\
\hline Anahuac original & $167 \mathrm{c}$ & $403 d$ & $6 c$ & 192 \\
\hline IAC-60 & $1,882 \mathrm{a}$ & $2,056 \mathrm{a}$ & $1,049 \mathrm{a}$ & 1,662 \\
\hline IAC-24 & $1,188 \mathrm{ab}$ & $1,375 \mathrm{abc}$ & $1,063 \mathrm{a}$ & 1,209 \\
\hline F (Years) & - & - & - & $20.21 * *$ \\
\hline F (Genotypes) & - & - & - & $11.12 * *$ \\
\hline $\mathrm{F}(\mathrm{G} \times \mathrm{Y})$ & - & - & - & $3.20 * *$ \\
\hline LSD (Tukey 5\%) & 9.57 & 9.57 & 9.57 & - \\
\hline C.V. (\%) & 9.70 & 13.72 & 10.91 & 11.80 \\
\hline
\end{tabular}

(1) Means followed by the same letter did not differ by the Tukey test. ${ }^{(2)}$ Value obtained with data transformed to $\sqrt{\mathrm{x}}$.**Significant at $1 \%$ level of probability. 
mutants 27 and 28 were slightly higher (Table 5). In 1995, only mutants 19 and 22 were similar to the control and the others were higher; in 1996 all the mutants were higher than the control.

There was a significant year interaction in Monte Alegre do Sul (Table 5). Comparison between mutants and the original cultivar showed that seven mutants were higher than the original cultivar. This could indicate the occurrence of a mutation which affected the plant height, besides aluminum toxicity tolerance. The greater height of these mutants could be an undesirable characteristic for lodging. However, the mutants did not differ from the control for this characteristic in this location (Table 4).

\section{Flowering cycle}

The significance of genotypes, years, genotypes $\mathrm{x}$ years, and mean flowering cycles for the three

Table 3. Mean grain yield (kg/ha) of wheat genotypes in experiments at Monte Alegre do Sul, in the years of 1994 and $1995^{(1)}$.

\begin{tabular}{lccc}
\hline Genotypes & 1994 & 1995 & $1994 / 95$ \\
\hline Anahuac mutant 18 & 3,354 & 2,243 & $2,799 \mathrm{a}$ \\
Anahuac mutant 19 & 3,070 & 2,354 & $2,712 \mathrm{a}$ \\
Anahuac mutant 20 & 3,264 & 2,611 & $2,938 \mathrm{a}$ \\
Anahuac mutant 21 & 3,542 & 2,333 & $2,937 \mathrm{a}$ \\
Anahuac mutant 22 & 3,333 & 2,069 & $2,676 \mathrm{a}$ \\
Anahuac mutant 23 & 3,507 & 2,042 & $2,774 \mathrm{a}$ \\
Anahuac mutant 24 & 2,653 & 2,125 & $2,389 \mathrm{ab}$ \\
Anahuac mutant 25 & 2,216 & 1,632 & $1,924 \mathrm{~b}$ \\
Anahuac mutant 26 & 3,445 & 2,500 & $2,972 \mathrm{a}$ \\
Anahuac mutant 27 & 3,570 & 2,493 & $3,031 \mathrm{a}$ \\
Anahuac mutant 28 & 3,049 & 2,250 & $2,649 \mathrm{a}$ \\
Anahuac original & 3,285 & 2,104 & $2,694 \mathrm{a}$ \\
IAC-60 & 3,403 & 2,805 & $3,104 \mathrm{a}$ \\
IAC-24 & 3,097 & 2,254 & $2,566 \mathrm{ab}$ \\
\hline F (Years) & - & - & $148.72 * *$ \\
F (Genotypes) & - & - & $5.34 * *$ \\
F (G x Y) & - & - & $1.46^{\mathrm{ns}}$ \\
LSD. (Tukey 5\%) & - & - & 0.3037 \\
C.V. (\%) & 13.40 & 10.14 & 2.61 \\
\hline
\end{tabular}

(1) Means followed by the same letter did not differ by the Tukey test. ${ }^{(2)}$ Value obtained with data transformed to $\log \mathrm{x} .{ }^{\mathrm{ns}}$ Nonsignificant. ${ }^{* *}$ Significant at $1 \%$ of probability. experiments set up at Capão Bonito are shown in Table 6. It was observed that the flowering cycle in 1994 and 1995, when compared with 1996, was lower for all genotypes. The higher temperatures in these years were responsible for this reduction. When the mutants were compared with the original cultivar, it can be seen that in 1994 there were differences in the cycle only for mutant 25 (longer cycle). In 1995, the cycles were similar and in 1996 only mutant 26, with a smaller cycle, differed from the control. Therefore, under these conditions with the exception of mutants 25 and 26, all others had similar flowering time as the original Anahuac cultivar.

In Monte Alegre do Sul, Table 6 indicates that in 1994 six mutants $(19,22,23,24,26$ and 27) were earlier and five (18, 20, 21, 25 and 28) had cycles similar to the original Anahuac. In 1995 all the mutants had similar flowering comparatively to the original cultivar.

\section{Maturity}

The results from Capão Bonito (Table 7) indicate a significant interaction among genotype and years. When the mutants were compared with the original cultivar in 1994, only mutant 25 had similar maturity, while all other mutants were earlier. In 1995, ten mutants were cycle similar to the control and mutant 25 had the latest flowering. In 1996, the mutants 24, 26, 27, and 28 were earlier than Anahuac and the others had a similar cycle. This suggests that in 1994 climatic factors were responsible for the different behavior of the mutants in relation to maturity cycle. In the other years, the majority of the mutants had the same cycle or were much earlier than the original cultivar (except for mutant 25 which was later in 1995). It is well known that greater earliness may be an advantage and from this point of view this alteration did not disqualify the mutant. It must be said, however, that the original Anahuac is not recommended for planting under acid soil conditions and that when this happens, as in the present experiment, poor plant development is observed and therefore comparisons of the maturity cycle as well as other characteristics under these conditions should be taken with caution.

In Monte Alegre do Sul (Table 7) the mutants showed similar maturity to the original cultivar in 
both 1994 and 1995 years. Under corrected soil conditions the Anahuac cultivar expressed its true maturity cycle. This seems to indicate that there was no mutation affecting the maturity cycle of some mutants as could have been expected considering the Capão Bonito data.

\section{Other characteristics}

The data indicate that differences exist between the mutants and the original Anahuac cultivar for all the assessed traits (Table 8). These differences varied among the mutants according to the trait. For those traits where differences were found, the mutants had higher or lower values comparatively to the control. For spike length, nine mutants were similar to the control and two had higher values. For the number of grains per spike, four mutants had similar values and seven lower values. These assessed characteristics are quantitative and were not the primary objective of the selection made to obtain the mutants. Long studies carried out on induced wheat mutants (Borojevic \& Sesek, 1981) indicated that alterations in quantitative characteristics were common and thus the breeder should assess the mutants obtained for various years and locations. These alterations may positively or negatively affect the yield. In the present study, these characteristics were preliminarily assessed in one year and one location. Nevertheless, certain inferences may be made based on the Monte Alegre do Sul data especially those which did not show genotype $x$ year interaction (Table 3 ). When the general means were compared, the mutants had similar yield to that of the original Anahuac (except mutant 25, which yielded less). The alterations (positive or negative) observed in the mutant for these characteristics did not alter grain production. This may be explained by a compensation mechanism among them. For example, in the case of mutant 23 there was an increase in spike length, number of spikelet per spike and in the weight of a hundred

Table 4. Lodging mean ( 0 = least lodging; 5 = maximum lodging $)$ of plants in the experiments at Capão Bonito and Monte Alegre do Sul (MAS), in the years 1994/1996(1).

\begin{tabular}{|c|c|c|c|c|c|}
\hline \multirow[t]{2}{*}{ Genotypes } & \multicolumn{4}{|c|}{ Capão Bonito } & \multirow{2}{*}{$\begin{array}{l}\text { MAS } \\
94 / 95 \\
\end{array}$} \\
\hline & 1994 & 1995 & 1996 & 94/96 & \\
\hline Anahuac mutant 18 & $1.25 \mathrm{a}$ & $0.50 \mathrm{a}$ & $1.25 \mathrm{a}$ & 1.00 & $3.25 \mathrm{a}$ \\
\hline Anahuac mutant 19 & $0.75 \mathrm{ab}$ & $0.00 \mathrm{a}$ & $0.75 \mathrm{ab}$ & 0.50 & $1.38 \mathrm{abcd}$ \\
\hline Anahuac mutant 20 & $1.50 \mathrm{ab}$ & $0.25 \mathrm{a}$ & $1.25 \mathrm{a}$ & 1.00 & $2.50 \mathrm{abc}$ \\
\hline Anahuac mutant 21 & $0.75 \mathrm{ab}$ & $0.00 \mathrm{a}$ & $1.50 \mathrm{a}$ & 0.75 & $2.63 \mathrm{ab}$ \\
\hline Anahuac mutant 22 & $1.00 \mathrm{a}$ & $0.00 \mathrm{a}$ & $1.25 \mathrm{a}$ & 0.75 & 2.13abcd \\
\hline Anahuac mutant 23 & $1.75 \mathrm{a}$ & $0.00 \mathrm{a}$ & $1.25 \mathrm{a}$ & 1.00 & $2.25 \mathrm{abc}$ \\
\hline Anahuac mutant 24 & $1.00 \mathrm{a}$ & $0.25 \mathrm{a}$ & $1.00 \mathrm{a}$ & 0.75 & 1.13abcd \\
\hline Anahuac mutant 25 & $0.75 \mathrm{ab}$ & $0.00 \mathrm{a}$ & $0.00 \mathrm{~b}$ & 0.25 & $0.13 d$ \\
\hline Anahuac mutant 26 & $1.00 \mathrm{a}$ & $0.00 \mathrm{a}$ & $1.75 \mathrm{a}$ & 0.92 & $2.63 \mathrm{ab}$ \\
\hline Anahuac mutant 27 & $0.75 \mathrm{ab}$ & $0.00 \mathrm{a}$ & $1.25 \mathrm{a}$ & 0.67 & $2.62 \mathrm{ab}$ \\
\hline Anahuac mutant 28 & $1.00 \mathrm{a}$ & $0.00 \mathrm{a}$ & $1.75 \mathrm{a}$ & 0.92 & $2.75 \mathrm{ab}$ \\
\hline Anahuac original & $0.00 \mathrm{~b}$ & $0.25 \mathrm{a}$ & $0.00 \mathrm{~b}$ & 0.08 & $0.75 \mathrm{abcd}$ \\
\hline IAC-60 & $0.00 \mathrm{~b}$ & $0.00 \mathrm{a}$ & $0.75 \mathrm{ab}$ & 0.25 & $0.88 \mathrm{~cd}$ \\
\hline IAC-24 & $2.00 \mathrm{a}$ & $0.00 \mathrm{a}$ & $0.75 \mathrm{ab}$ & 0.92 & $0.63 \mathrm{~cd}$ \\
\hline F (Years) & & & & $28.19 *$ & $71.15^{* *}$ \\
\hline F (Genotypes) & & & & $2.02 *$ & $6.82 * *$ \\
\hline$F(G \times Y)$ & & & & $2.85 * *$ & $0.89^{\mathrm{ns}}$ \\
\hline LSD (Tukey 5\%) & $0.4977^{(2)}$ & $0.4977^{(2)}$ & $0.4977^{(2)}$ & & $0.7564^{(3)}$ \\
\hline C.V. (\%) & & & & 2.54 & 27.62 \\
\hline
\end{tabular}

(1) Means followed by the same letter do not differ by Tukey test at $5 \%$ level of probability. ${ }^{(2)}$ Value obtained with data transformed to $1 / \sqrt{\mathrm{x}+0,5}$. ${ }^{(3)}$ Value obtained by the data transformed to $\sqrt{\mathrm{x}}$. ${ }^{\mathrm{ns}}$ Nonsignificant. * Significant at $5 \%$ of probability. * Significant at $1 \%$ of probability. 
Table 5. Plant height mean (in cm) in the experiments at Capão Bonito and Monte Alegre do Sul (MAS), 1994/1996 ${ }^{(1)}$.

\begin{tabular}{|c|c|c|c|c|c|}
\hline \multirow[t]{2}{*}{ Genotypes } & \multicolumn{4}{|c|}{ Capão Bonito } & \multirow{2}{*}{$\begin{array}{l}\text { MAS } \\
94 / 95\end{array}$} \\
\hline & 1994 & 1995 & 1996 & $94 / 96$ & \\
\hline Anahuac mutant 18 & 73.75abcd & $78.75 \mathrm{abc}$ & $75.00 \mathrm{~cd}$ & 75.83 & $112 \mathrm{a}$ \\
\hline Anahuac mutant 19 & $70.00 \mathrm{bcd}$ & $66.25 \mathrm{~cd}$ & $65.00 \mathrm{~d}$ & 67.08 & $91 \mathrm{bcd}$ \\
\hline Anahuac mutant 20 & 78.75abcd & $80.00 \mathrm{abc}$ & $75.00 \mathrm{~cd}$ & 77.92 & $96 b c$ \\
\hline Anahuac mutant 21 & 77.50abcd & $81.25 \mathrm{abc}$ & $76.25 \mathrm{bcd}$ & 78.33 & $98 b c$ \\
\hline Anahuac mutant 22 & $72.50 \mathrm{abcd}$ & $67.50 \mathrm{~cd}$ & $68.75 d$ & 69.58 & $94 \mathrm{bcd}$ \\
\hline Anahuac mutant 23 & 73.75abcd & $78.75 \mathrm{abc}$ & $72.50 \mathrm{~cd}$ & 75.00 & $94 \mathrm{bcd}$ \\
\hline Anahuac mutant 24 & $67.50 \mathrm{~cd}$ & $73.75 b c$ & $67.50 \mathrm{~d}$ & 69.58 & $99 b$ \\
\hline Anahuac mutant 25 & $67.50 \mathrm{bcd}$ & $78.75 \mathrm{abc}$ & $70.00 \mathrm{~d}$ & 72.08 & $86 \mathrm{~cd}$ \\
\hline Anahuac mutant 26 & 72.50abcd & $87.50 \mathrm{a}$ & $92.50 \mathrm{a}$ & 84.17 & $113 a$ \\
\hline Anahuac mutant 27 & $82.50 \mathrm{ab}$ & $86.25 \mathrm{ab}$ & $85.00 \mathrm{abc}$ & 84.58 & $114 \mathrm{a}$ \\
\hline Anahuac mutant 28 & $80.00 \mathrm{abc}$ & $80.00 \mathrm{abc}$ & $88.75 \mathrm{ab}$ & 82.92 & $113 \mathrm{a}$ \\
\hline Anahuac original & $62.50 \mathrm{~d}$ & $52.50 \mathrm{~d}$ & $26.25 \mathrm{e}$ & 47.08 & $83 d$ \\
\hline IAC-60 & $85.00 \mathrm{a}$ & $83.75 \mathrm{ab}$ & $73.75 \mathrm{~cd}$ & 80.83 & $96 b c$ \\
\hline IAC-24 & $68.75 \mathrm{bcd}$ & $67.50 \mathrm{~cd}$ & $67.50 \mathrm{~d}$ & 67.92 & $86 \mathrm{~cd}$ \\
\hline $\mathrm{F}$ (Years) & & & & $1.39^{\mathrm{ns}}$ & $41.26 * *$ \\
\hline F (Genotypes) & & & & $7.52 * *$ & $24.82 * *$ \\
\hline$F(G \times Y)$ & & & & $3.10 * *$ & $1.23^{\mathrm{ns}}$ \\
\hline LSD (Tukey $5 \%)^{(2)}$ & 2212.39 & 2212.39 & 2212.39 & & 12 \\
\hline C.V. $(\%)$ & & & & 16.31 & 5.62 \\
\hline
\end{tabular}

Table 6. Mean cycle (in days) from emergence to flowering in the experiments at Capão Bonito and Monte Alegre do Sul, 1994/1996(1).

\begin{tabular}{|c|c|c|c|c|c|c|c|}
\hline \multirow[t]{2}{*}{ Genotypes } & \multicolumn{4}{|c|}{ Capão Bonito } & \multicolumn{3}{|c|}{ Monte Alegre do Sul } \\
\hline & 1994 & 1995 & 1996 & $1994 / 96$ & 1994 & 1995 & $1994 / 95$ \\
\hline Anahuac mutant 18 & $47.00 \mathrm{~cd}$ & $46.00 \mathrm{bc}$ & $67.00 \mathrm{ab}$ & 53.33 & $69.75 \mathrm{bcd}$ & $68.75 \mathrm{abc}$ & 69.25 \\
\hline Anahuac mutant 19 & $50.00 \mathrm{bcd}$ & $47.75 \mathrm{abc}$ & $70.50 \mathrm{ab}$ & 56.00 & $69.00 \mathrm{~cd}$ & $67.25 \mathrm{bc}$ & 68.13 \\
\hline Anahuac mutant 20 & $48.75 b c d$ & $46.00 \mathrm{bc}$ & $70.50 \mathrm{ab}$ & 55.10 & $70.25 \mathrm{bcd}$ & $68.75 \mathrm{abc}$ & 69.50 \\
\hline Anahuac mutant 21 & $50.75 b c$ & $46.00 \mathrm{bc}$ & $74.00 \mathrm{a}$ & 56.92 & $70.25 \mathrm{bcd}$ & $70.25 \mathrm{abc}$ & 70.25 \\
\hline Anahuac mutant 22 & $48.25 \mathrm{bcd}$ & $47.75 \mathrm{abc}$ & $68.75 \mathrm{ab}$ & 54.92 & $69.00 \mathrm{~cd}$ & $69.25 \mathrm{abc}$ & 69.13 \\
\hline Anahuac mutant 23 & $47.00 \mathrm{~cd}$ & $44.75 \mathrm{c}$ & $70.50 \mathrm{ab}$ & 54.08 & $68.00 \mathrm{~cd}$ & $69.75 \mathrm{abc}$ & 68.88 \\
\hline Anahuac mutant 24 & $45.25 \mathrm{~cd}$ & $42.25 c$ & $63.50 \mathrm{ab}$ & 50.33 & $64.00 \mathrm{~d}$ & $66.50 \mathrm{c}$ & 65.25 \\
\hline Anahuac mutant 25 & $68.00 \mathrm{a}$ & $52.25 \mathrm{ab}$ & $74.00 \mathrm{a}$ & 64.75 & $76.00 \mathrm{abc}$ & $74.00 \mathrm{abc}$ & 75.00 \\
\hline Anahuac mutant 26 & $45.25 \mathrm{~cd}$ & $44.75 c$ & $61.75 b$ & 50.58 & $68.00 \mathrm{~cd}$ & $67.25 \mathrm{bc}$ & 67.63 \\
\hline Anahuac mutant 27 & $45.75 \mathrm{~cd}$ & $44.75 c$ & $67.00 \mathrm{ab}$ & 52.50 & $68.00 \mathrm{~cd}$ & $68.00 \mathrm{bc}$ & 68.00 \\
\hline Anahuac mutant 28 & $44.00 \mathrm{~d}$ & $46.00 \mathrm{bc}$ & $63.50 \mathrm{ab}$ & 51.17 & $68.25 \mathrm{bcd}$ & $66.25 c$ & 67.75 \\
\hline Anahuac original & $50.00 \mathrm{bcd}$ & $47.75 \mathrm{abc}$ & $74.00 \mathrm{a}$ & 57.25 & $77.25 \mathrm{ab}$ & $73.75 \mathrm{abc}$ & 75.50 \\
\hline IAC -60 & $58.50 \mathrm{a}$ & $51.75 \mathrm{ab}$ & $74.00 \mathrm{a}$ & 64.42 & $79.50 \mathrm{a}$ & $75.00 \mathrm{ab}$ & 77.25 \\
\hline IAC 24 & $55.25 \mathrm{ab}$ & $54.50 \mathrm{a}$ & $72.25 \mathrm{a}$ & 60.67 & $74.75 \mathrm{abc}$ & $76.25 \mathrm{a}$ & 75.50 \\
\hline F (Years) & - & - & - & $222.52 * *$ & - & - & $2.49^{\mathrm{ns}}$ \\
\hline F (Genotypes) & - & - & - & $6.78 * *$ & - & - & $13.27 * *$ \\
\hline$F(G \times Y)$ & - & - & - & $3.04 * *$ & - & - & $2.44 * *$ \\
\hline LSD (Tukey 5\%) & $0.00885^{(2}$ & $0.00885^{(2)}$ & $0.00885^{(2)}$ & - & 8.21 & 8.21 & - \\
\hline C.V. $(\%)$ & - & - & - & 1.46 & - & - & 2.61 \\
\hline
\end{tabular}


Table 7. Mean cycle (in days) from emergence to maturity in the experiments of Capão Bonito and Monte Alegre do Sul, 1994/96 $6^{(1)}$.

\begin{tabular}{|c|c|c|c|c|c|c|c|}
\hline \multirow[t]{2}{*}{ Genotypes } & \multicolumn{4}{|c|}{ Capão Bonito } & \multicolumn{3}{|c|}{ Monte Alegre do Sul } \\
\hline & 1994 & 1995 & 1996 & $1994 / 96$ & 1994 & 1995 & $1994 / 95$ \\
\hline Anahuac mutant 18 & $113.00 \mathrm{~b}$ & $118.75 b$ & $128.50 \mathrm{abc}$ & 120.10 & $113.00 \mathrm{~b}$ & $114.00 \mathrm{abc}$ & 113.50 \\
\hline Anahuac mutant 19 & $114.75 b$ & $118.75 b$ & $130.25 \mathrm{ab}$ & 121.25 & $112.75 b$ & $112.25 b c$ & 112.50 \\
\hline Anahuac mutant 20 & $113.00 \mathrm{~b}$ & $117.00 \mathrm{~b}$ & $130.50 \mathrm{ab}$ & 120.17 & $114.25 b$ & $114.25 \mathrm{abc}$ & 114.25 \\
\hline Anahuac mutant 21 & $116.50 \mathrm{~b}$ & $117.00 \mathrm{~b}$ & $132.00 \mathrm{a}$ & 121.83 & $113.75 b$ & $115.75 \mathrm{abc}$ & 114.75 \\
\hline Anahuac mutant 22 & $113.00 \mathrm{~b}$ & $117.00 \mathrm{~b}$ & $130.25 \mathrm{ab}$ & 120.08 & $112.75 b$ & $112.50 \mathrm{bc}$ & 112.63 \\
\hline Anahuac mutant 23 & $113.00 \mathrm{~b}$ & $117.00 \mathrm{~b}$ & $130.25 \mathrm{ab}$ & 120.08 & $112.75 b$ & $112.75 b c$ & 112.75 \\
\hline Anahuac mutant 24 & $113.00 \mathrm{~b}$ & $117.00 \mathrm{~b}$ & $125.00 \mathrm{c}$ & 118.33 & $112.75 b$ & $111.00 \mathrm{c}$ & 118.88 \\
\hline Anahuac mutant 25 & $127.00 \mathrm{a}$ & $124.00 \mathrm{a}$ & $133.00 \mathrm{a}$ & 128.00 & $112.75 b$ & $124.00 \mathrm{a}$ & 118.38 \\
\hline Anahuac mutant 26 & $113.00 \mathrm{~b}$ & $118.75 \mathrm{ab}$ & $125.00 \mathrm{c}$ & 118.92 & $113.00 \mathrm{~b}$ & $112.75 b c$ & 112.88 \\
\hline Anahuac mutant 27 & $113.00 \mathrm{~b}$ & $122.25 \mathrm{ab}$ & $126.75 b c$ & 120.67 & $113.00 \mathrm{~b}$ & $115.75 \mathrm{abc}$ & 114.38 \\
\hline Anahuac mutant 28 & $113.00 \mathrm{~b}$ & $117.00 \mathrm{~b}$ & $125.00 \mathrm{c}$ & 118.33 & $113.00 \mathrm{~b}$ & $115.75 \mathrm{abc}$ & 114.38 \\
\hline Anahuac original & $127.00 \mathrm{a}$ & $117.00 \mathrm{~b}$ & $133.00 \mathrm{a}$ & 125.67 & $116.75 \mathrm{ab}$ & $114.00 \mathrm{abc}$ & 115.38 \\
\hline IAC -60 & $127.00 \mathrm{a}$ & $124.00 \mathrm{a}$ & $132.00 \mathrm{a}$ & 127.67 & $126.00 \mathrm{a}$ & $124.00 \mathrm{abc}$ & 125.00 \\
\hline IAC 24 & $127.00 \mathrm{a}$ & $124.00 \mathrm{a}$ & $132.50 \mathrm{a}$ & 127.83 & $118.25 \mathrm{ab}$ & $122.25 \mathrm{ab}$ & 120.25 \\
\hline F (Years) & - & - & - & $61.30 * *$ & - & - & $1.50^{\mathrm{ns}}$ \\
\hline F (Genotypes) & - & - & - & $3.95 * *$ & - & - & $8.17 * *$ \\
\hline$F(G \times Y)$ & - & - & - & $8.68 * *$ & - & - & $4.01 * *$ \\
\hline LSD (Tukey 5\%) & 5.16 & 5.16 & 5.16 & - & 10.80 & 10.80 & - \\
\hline C.V. $(\%)$ & - & - & - & 1.75 & - & - & 1.64 \\
\hline
\end{tabular}

(1) Means followed by the same letter do not differ by the Tukey test at $5 \%$ level of probability. ${ }^{\mathrm{ns}}$ Nonsignificant. ${ }^{* * *}$ Significant at $1 \%$ of probability.

Table 8. Mean data for spike length, number of spikelets per spike, number of grains per ear and per spikelet and weight of a hundred grains for the wheat genotypes analyzed in the experiments at Monte Alegre do Sul in 1994(1).

\begin{tabular}{|c|c|c|c|c|c|}
\hline Genotypes & $\begin{array}{l}\text { Spike length } \\
(\mathrm{cm})\end{array}$ & $\begin{array}{l}\text { Spikelets/ } \\
\text { spike (no) }\end{array}$ & $\begin{array}{c}\text { Grains/ } \\
\text { spike (no) }\end{array}$ & $\begin{array}{c}\text { Grains/ } \\
\text { spikelet (no) }\end{array}$ & $\begin{array}{c}\text { Weight of } \\
100 \text { grains }(\mathrm{g})\end{array}$ \\
\hline Anahuac mutant 18 & $8.1 \mathrm{cdef}$ & $19.2 \mathrm{~cd}$ & $31.9 \mathrm{cde}$ & $1.65 \mathrm{bc}$ & $4.41 \mathrm{a}$ \\
\hline Anahuac mutant 19 & 7.5efg & $17.8 \mathrm{e}$ & $28.9 \mathrm{e}$ & $1.61 \mathrm{bc}$ & $4.05 \mathrm{ab}$ \\
\hline Anahuac mutant 20 & $8.1 \mathrm{cdef}$ & $19.5 \mathrm{c}$ & $31.8 \mathrm{cde}$ & $1.62 \mathrm{bc}$ & $4.41 \mathrm{a}$ \\
\hline Anahuac mutant 21 & $8.3 \mathrm{bcd}$ & $20.4 b c$ & $31.0 \mathrm{de}$ & $1.50 \mathrm{c}$ & $4.21 \mathrm{a}$ \\
\hline Anahuac mutant 22 & $8.2 \mathrm{bcde}$ & $18.9 \mathrm{bc}$ & $31.9 \mathrm{cde}$ & $1.69 \mathrm{bc}$ & $4.07 \mathrm{ab}$ \\
\hline Anahuac mutant 23 & $8.5 \mathrm{abc}$ & $20.0 \mathrm{bc}$ & 34.6abcde & $1.72 b c$ & $4.15 \mathrm{a}$ \\
\hline Anahuac mutant 24 & $7.0 \mathrm{~g}$ & $17.7 \mathrm{e}$ & $31.7 \mathrm{cde}$ & $1.78 b c$ & $4.16 \mathrm{a}$ \\
\hline Anahuac mutant 25 & $8.9 \mathrm{ab}$ & $24.2 \mathrm{a}$ & 36.6abcd & $1.50 \mathrm{c}$ & $3.75 \mathrm{c}$ \\
\hline Anahuac mutant 26 & $7.4 \mathrm{fg}$ & $17.5 \mathrm{e}$ & $32.2 \mathrm{cde}$ & $1.82 \mathrm{abc}$ & $4.30 \mathrm{a}$ \\
\hline Anahuac mutant 27 & $7.2 \mathrm{~g}$ & $17.5 \mathrm{e}$ & $32.9 \mathrm{bcde}$ & $1.84 \mathrm{abc}$ & $3.92 \mathrm{abc}$ \\
\hline Anahuac mutant 28 & $7.4 \mathrm{fg}$ & $17.3 \mathrm{e}$ & 33.5 bcde & $1.92 \mathrm{ab}$ & $4.20 \mathrm{a}$ \\
\hline Anahuac original & 7.6defg & $17.9 \mathrm{de}$ & $40.8 \mathrm{ab}$ & $2.26 \mathrm{a}$ & $3.42 \mathrm{c}$ \\
\hline IAC-60 & $9.0 \mathrm{a}$ & $24.4 \mathrm{a}$ & $42.1 \mathrm{a}$ & $1.71 b c$ & $3.60 \mathrm{bc}$ \\
\hline IAC-24 & $8.1 \mathrm{cdef}$ & $20.4 b$ & $39.1 \mathrm{abc}$ & $1.91 \mathrm{ab}$ & $3.55 \mathrm{bc}$ \\
\hline F (Genotypes) & $17.62 * *$ & $77.05 * *$ & $7.01 * *$ & $5.96 * *$ & $10.72 * *$ \\
\hline C.V. $(\%)$ & 3.71 & 2.71 & 8.01 & 4.31 & 5.19 \\
\hline LSD (Tukey 5\%) & 0.743 & $1.376^{(2)}$ & $0.006^{(2)}$ & $0.0828^{(3)}$ & 0.5321 \\
\hline
\end{tabular}

(1) Means followed by the same letter did not differ by the Tukey test. ${ }^{(2)}$ Value obtained with data transformed to $1 / x$. $^{(3)}$ Value obtained with data transformed to $1 / \sqrt{\mathrm{x}} \cdot * *$ Significant at $1 \%$ of probability. 
grains. The number of grains per spike was similar, but the mutant had a lower number of grains per spikelet, so there was a compensation which resulted in similar yield. For the majority of the mutants evaluated such compensations were observed. The exception was mutant 25 which produced less than the original Anahuac cultivar probably because even though it had a longer spike and greater number of spikelets per spike, the number of grains per spikelet was greatly reduced.

\section{Conclusions}

1. Eleven mutant lines obtained by gamma-ray radiation from the Anahuac cultivar are higher yielding than the original Anahuac cultivar in acid soil under upland conditions; the majority of mutant lines has similar yield to the IAC-60 and IAC-24 cultivars, which are tolerant to aluminum toxicity.

2. Ten mutant lines and the controls Anahuac, IAC-60 and IAC-24 do not differ among themselves for grain yield in corrected soils under sprinkle irrigation.

3. These mutants are indicated as a substitute for the Anahuac cultivar for acid soil.

4. Aluminum tolerant lines with good agronomic characteristics are obtained from susceptible cultivar by mutation induction.

\section{Acknowledgements}

To Cooperatives of the Paranapanema Valley; to FAPESP and to International Atomic Energy Agency, Vienna, Austria, for supporting this study.

\section{References}

BARRIGA, P.; FUENTES, R.; SEEMANN, P.; MANQUIÁN, N. Yield stability of wheat mutant lines. In: INTERNATIONAL ATOMIC ENERGY AGENCY (Vienna, Austria). The use of mutation techniques for crop improvement in Latin America. Vienna, 1996. p. 141-148.

BOROJEVIC, K.; SESEK, S. Process influencing the evolution of irradiated wheat populations. In: INTERNATIONAL ATOMIC ENERGY AGENCY
(Vienna, Austria). Induced mutation: a tool in plant research. Vienna, 1981. p. 127-141.

CAMARGO, C. E. de O. Trigo. In: FURLANI, A. M. C.; VIEGAS, G. P. (Ed.). Melhoramento de plantas no Instituto Agronômico de Campinas. Campinas : Instituto Agronômico, 1993. p. 433-488.

CAMARGO, C. E. de O.; FELICIO, J. C.; FERREIRA FILHO, A. W. P.; BARROS, B. de C.; FREITAS, J. G. de; PETTINELLI JÚNIOR, A.; GALLO, P. B.; KANTHACK, R. A. D. Melhoramento do trigo. XXVIII. Novos genótipos oriundos de populações híbridas introduzidas de Oregon (USA) no Estado de São Paulo. Bragantia, Campinas, v. 50, p. 225-246, 1991.

CAMARGO, C. E. de O.; FELICIO, J. C.; FERREIRA FILHO, A. W. P.; PETTINELLI JÚNIOR, A.; TULMANN NETO, A.; ANDO, A. Mutation breeding of wheat in São Paulo State, Brazil. In: INTERNATIONAL ATOMIC ENERGY AGENCY (Vienna, Austria). The use of mutation techniques for crop improvement in Latin America. Vienna, 1996. p. 95-111.

CAMARGO, C. E. de O.; FELICIO, J. C.; ROCHA JÚNIOR, L. S. Trigo: tolerância ao alumínio em solução nutritiva. Bragantia, Campinas, v. 46, p. 183-190, 1987.

CAMARGO, C. E. de O.; OLIVEIRA, O. F. Tolerância de cultivares de trigo a diferentes níveis de alumínio em solução nutritiva e no solo. Bragantia, Campinas, v. 40, p. 21-31, 1981.

DONINI, B.; KAWAI, T.; MICKE, A. Spectrum of mutant characters utilized in developing improved cultivars. In: INTERNATIONAL ATOMIC ENERGY AGENCY (Vienna, Austria). Selection in mutation breeding. Vienna, 1984. p. 7-31.

FELICIO, J. C.; CAMARGO, C. E. de O.; GERMANI, R.; GALLO, P. B.; CASTRO, J. L.; KANTHACK, R. A. D. Melhoramento do trigo. XXXII. Avaliação de novos genótipos derivados do IAC 24 quanto às características agronômicas e à qualidade tecnológica. Bragantia, Campinas, v. 57, p. 61-80, 1998.

INSTITUTO AGRONÔMICO (Campinas, São Paulo). Recomendações da Comissão Técnica de Trigo da Secretaria de Agricultura e Abastecimento do Estado de São Paulo. Campinas, 1996. 68 p. (IAC. Boletim Técnico, 167).

MALUSZYNSKI, M.; AHLOOWALIA, B. S.; SIBURJORNSSON, B. Application of in vivo and in vitro 
mutation techniques for crop improvement. Euphytica, Dordrecht, v. 85, p. 303-315, 1995.

POEHLMANN, J. M.; SLEPER, D. A. Breeding wheat. In: - Breeding field crops. Ames : Iowa State University Press, 1995. p. 259-277.

RAY, B. V.; SILVA, N. M.; BATAGLIA, O. C.; QUAGGIO, J. A.; CANTARELLA, H.; BELINAZZI JÚNIOR, R.; DECHEN, A. R.; TRANI, P. E. Recomen- dações de adubação e calagem para o Estado de São Paulo. Campinas : Instituto Agronômico, 1985. 107 p. (IAC. Boletim Técnico, 100).

TULMANN NETO, A.; CAMARGO, C. E. de O.; ALVES, M. P.; PETTINELLI JÚNIOR, A.; FERREIRA FILHO, A. W. P. Redução na altura de planta e resistência às doenças no cultivar de trigo (Triticum aestivum L.) IAC-19 através de indução de mutações. Revista Brasileira de Genética, Ribeirão Preto, v. 19, p. 275-281, 1996. 